\title{
BRANDED CONTENT E NARCISISMO: UMA ANÁLISE DO CASE THE HIRE DA BMW $^{1}$
}

\author{
Ana Rachel Zimmermann de Quadros² \\ Christian Luiz Melim Schwartz ${ }^{3}$
}

\section{Resumo}

A publicidade evoluiu com o passar do tempo, pois surgiu a necessidade de se criar novas estratégias para atingir um novo tipo de consumidor: o digital. Esse público já não pode ser exposto à publicidade comum, é preciso saber comunicar-se como esses novos indivíduos. Através do estudo de uma estratégia de marketing chamada branded content, este artigo irá analisar a narrativa utilizada no case The Hire, da BMW, e relacioná-la ao sucesso da campanha. Além disso, irá traçar uma ligação entre o consumidor digital e o narcisismo.

Palavras-chave: Publicidade, branded content, narcisismo, narrativas digitais.

\begin{abstract}
Advertising has evolved over time because the need has arisen to create new strategies in order to reach consumers who have gone digital. This audience can no longer be exposed to traditional advertising; one must now know how to communicate with these new individuals. Through the study of a marketing strategy called branded content, this article will analyse the narrative used by The Hire, a BMW advertising campaign, and relate it to the campaign's success. Moreover, it will draw a connection between the digital consumer and the concept of narcissism.
\end{abstract}

Keywords: Advertising, branded content, narcissism, digital narratives.

\section{Introdução}

$\mathrm{O}$ crescimento rápido da internet repercutiu diretamente na publicidade. O receptor da mensagem já não é mais exposto a ela de forma "imposta" - como ocorre com a televisão, por exemplo; pelo contrário, é opção do receptor escolher o que e quando receber essa mensagem. Isso criou na publicidade a necessidade de se investir em novas estratégias de marketing para chegar a esse novo consumidor.

Algumas das novas estratégias de marketing que surgiram nos últimos anos puderam ser relacionadas com a internet de uma forma muito produtiva. Entre elas se encontra o branded content, que é uma estratégia que une a publicidade e o entretenimento, buscando ir

\footnotetext{
${ }^{1}$ Trabalho desenvolvido dentro do Projeto de Iniciação Científica (PIC) da Universidade Positivo entre os anos de 2012 e 1013.

${ }^{2}$ Graduada em Comunicação Social/Publicidade e Propaganda pela Universidade Positivo.

${ }^{3}$ Jornalista e mestre em Estudos Literários pela Universidade Federal do Paraná (UFPR). Doutorando em História na USP.
} 
além da comunicação tradicional, fazendo com que o público interaja e se relacione com uma marca, dando a esse consumidor entretenimento, conhecimento ou informação.

Estas novidades persuadem e encantam o consumidor justamente por não serem convencionais. Entender como o consumidor é atingido por essa mensagem e como ele a percebe é fundamental para determinar o efeito causado por ela, além de auxiliar na comunicação com esse novo público.

Este artigo pretende analisar questões relacionadas à narrativa no meio digital. Como comunicar-se com esse novo público, para entender como atingi-lo através de novas estratégias de publicidade. Para isso, a autora principal será Pollyana Ferrari, abordando as narrativas digitais, além de Henry Jenkins, falando sobre a convergência digital e demais autores de artigos na área da comunicação digital.

A seguir, será abordado o narcisismo. Freud será o principal autor neste momento. Traçando uma linha com o consumo, Lasch abordará o narcisismo na sociedade atual, apontando suas principais características.

Dentro da pesquisa documental, será analisado o case da campanha The Hire, criada pela agência publicitária Fallon para a marca de automóveis BMW, em 2001. Este case representa um dos primeiros casos da utilização da técnica de branded content. O estudo do case pretenderá traçar uma ligação entre os conceitos filosóficos e narrativos abordados no texto e os filmes da campanha.

\section{Narrativas digitais}

As mídias digitais abriram espaço para uma nova forma de interação entre as pessoas, consequentemente a forma de se comunicar nesse meio também sofreu alterações. A definição de mídias sociais é justamente a produção de conteúdos de forma descentralizada e sem o controle editorial de grandes grupos. Significa a produção de muitos para muitos.

A autora Pollyana Ferrari fala que é preciso saber comunicar-se com esse meio e que requer muito aprendizado, pois ao mesmo tempo em que eles recebem conteúdo, também são produtores de conteúdo.

Quando se analisam cases famosos de lutas sociais iniciadas por movimentos na internet, fica claro como esse público digital interfere na produção de conteúdo. A própria autora cita em seu texto o exemplo do caso do motorista que atropelou 16 ciclistas em Porto Alegre, como este caso ganhou voz no meio digital, principalmente no twitter, e chamou a 
atenção para casos de violência no trânsito. Muitos tweets de protesto foram registrados, fazendo com que a rede social se tornasse uma narrativa de protesto.

As narrativas passam a ser segmentadas, pois o conteúdo no meio da internet é segmentado. É isso que torna a internet um meio de comunicação único, pois diferentemente dos meios vistos como tradicionais, como a televisão, rádio e jornal, por exemplo, a internet permite que seu usuário selecione o conteúdo que quer acessar, dando-lhe a liberdade que outros meios não dão.

Mas o grande diferencial da internet é a interação que ela proporcionou entre o consumidor e a marca, entre consumir e produzir conteúdo. $\mathrm{O}$ usuário não se satisfaz apenas em receber uma informação, ele quer repassá-la. A narrativa de compartilhamento já faz parte da internet. Em seu artigo, Marquez (2011, p. 3) comenta que a criação das hashtags, em parte, justifica o aparecimento destas narrativas. A hashtag é o símbolo \#, que é colocado antes de alguma frase ou palavra. Isso une as pessoas em uma mesma conversa, sobre diversos assuntos, dos mais comuns aos mais engajados.

A autora Pollyana Ferrari cita em seu texto o autor Pierre Lévy, que fala: "Face ao futuro que nos espera, nenhuma referência, nenhuma autoridade, nenhum dogma e nenhuma certeza se mantém. Descobrimos que a realidade é uma criação compartilhada. Estamos todos na mesma rede".

Desta forma, os movimentos sociais ganham uma dimensão muito maior no mundo da internet. São milhares de pessoas falando sobre assuntos em comum em tempo real.

Cada um pode acrescentar informações da rede. Criam-se comunidades para debater assuntos em comum; as pessoas podem compartilhar conhecimento e experiências sobre um mesmo assunto. A internet permite que haja uma liberdade de expressão maior do que em qualquer outro meio de comunicação:

No meio das novas tecnologias, o advento da Internet reformulou a relação que tínhamos entre a tecnologia e a comunicação, pois pela primeira vez a conexão entre cada pessoa (representado seu segmento) e as demais que compartilham das mesmas ideias, graças aos mais diversos mecanismos de comunicação, torna-se possível e real (MARQUEZ, 2011, p.7).

Em seu livro Cultura de Convergência, Jenkins faz uma análise sobre a evolução das mídias, tanto do consumo quanto de produção. Através deste estudo, ele mostra um novo paradigma para entender a transformação midiática e cultural pela qual estamos passando e fala sobre a relação pessoal que o consumidor agora tem com as mídias: nesta evolução, a 
relação passou de interativa para participativa. Agora o consumidor é cortejado por diversos suportes de mídia, e a circulação de conteúdos depende fortemente da participação ativa dele.

\begin{abstract}
A convergência das mídias é mais do que apenas uma mudança tecnológica. A convergência altera a relação entre tecnologias existentes, indústrias, mercados, gêneros e públicos. A convergência altera a lógica pela qual a indústria midiática opera e pela qual os consumidores processam a notícia e o entretenimento (JENKINS, 2008, p. 41).
\end{abstract}

Antigamente, as mídias tendiam a ser substituídas umas pelas outras, e atualmente elas interagem entre si, permitindo que a convergência ocorra no indivíduo consumidor e em suas interações sociais com outros.

\title{
Um indivíduo narcisista
}

O crescimento do mundo digital, porém, trouxe à discussão uma questão muito antiga: a criação de um indivíduo narcisista.

A partir do estudo das psicoses, Freud cunhou o conceito de narcisismo, em que toda a energia psíquica estaria focada no eu. $\mathrm{O}$ termo narcisismo foi inspirado pela mitologia grega. Narciso, um jovem de beleza incomparável, desprezava todas as moças que se apaixonavam por ele. Uma das vítimas da rejeição de Narciso, Eco, recorreu aos poderes de Nêmesis, a deusa da vingança, que amaldiçoou Narciso: o jovem amaria e não poderia possuir o objeto amado. Um dia, ao se deparar com a imagem de sua beleza na superfície de um lago, ele se apaixonou perdidamente por si próprio. Tentando alcançar o seu amado de todas as maneiras possíveis, Narciso caiu dentro do lago e afogou-se. A partir desta história, Freud cunhou o termo narcisismo que significa autoadoração.

A autora Susan Liesenberg, ao abordar o narcisismo e as redes sociais, fala que fantasiamos todo um mundo dentro da internet para nos sentirmos realizados.

\footnotetext{
O surto narcizesco nos livra da frustração da realidade, porque nele concretizamos a fantasia que nos protege: somos homens e mulheres nota mil. Em pixels, configuramos medidas e características perfeitas intangíveis fora da manipulação dos bytes. Nos refugiamos em uma realidade paralela cujos códigos computacionais alteram nosso DNA digital e nos fazem renascer como gostaríamos - o que nem silicone, próteses, injeções e megahairs conseguem com tanta precisão e em tão pouco tempo (LIESENBERG, 2011, p.142).
}

O narcisismo não é exclusivo da atualidade: assim como o personagem principal da obra O Retrato de Dorian Gray, de Oscar Wilde, na sociedade atual este conceito 
psicanalítico torna-se evidente: as pessoas estão mais envolvidas com sua imagem. Dorian Gray é corrompido por sua beleza e pela ambição de ser eternamente jovem.

Preocupadas com a imagem projetada de si mesmas, muitas pessoas fazem uso de seu tempo e dinheiro em busca de produtos que lhes proporcionariam a aparência desejada. Segundo o historiador americano Christopher Lasch, os narcisistas se distinguem pela superficialidade das relações, não acreditam na possibilidade de transformar o futuro, ignoram o passado e vivem para o presente, desvinculando-se de qualquer continuidade histórica. Viver o presente e de forma exclusiva para si mesmo é o sentimento que domina o narcisista.

Os meios de comunicação de massa, com seu culto da celebridade e sua tentativa de cercá-la de encantamento e excitação, fizeram dos americanos uma nação de fãs, de frequentadores de cinema. A "mídia" dá substância e, por conseguinte, intensifica os sonhos narcisistas de fama e glória, encoraja o homem comum a identificar-se com as estrelas e a odiar o "rebanho", e torna-se cada vez mais difícil aceitar a banalidade da existência cotidiana (LASCH, 1983, p. 43).

A exagerada ênfase dada à importância de vencer é outra maneira da sociedade atual promover o narcisismo. A realidade de um indivíduo é dividida entre aspectos aceitos e rejeitados - estes últimos são projetados nas outras pessoas, ou seja, se a imagem narcisista é de vigor, a pessoa projetará em outros uma imagem frágil que deverá ser extinta.

Para o eu do prazer o mundo externo está dividido numa parte que é agradável, que ele incorporou a si mesmo, e num remanescente que lhe é estranho. [...] o sujeito do eu coincide com o prazer, e o mundo com o desprazer (FREUD, 1915, p. 157-158).

As mudanças sociais causam no homem um impacto psicológico, e o conceito de narcisismo desenvolvido por Lasch, é utilizado para compreender tal impacto.

As condições sociais predominantes tendem [...] a fazer aflorar os traços narcisistas presentes, em vários graus, em todos nós. Estas condições também transformaram a família, que por sua vez modela a estrutura subjacente da personalidade (LASCH, 1983, p. 76).

A tecnologia permitiu ao homem moderno a aquisição de um senso de poder nunca antes experimentado. O maior benefício recebido pelo indivíduo que detém o poder é a recompensa material e a sua imagem ideal projetada.

Com o foco no individual, vive-se uma cultura de imediatismo, em que a autossuperação é o que importa. A fabricação dos falsos desejos, que prometem a felicidade, leva o homem a perder suas referências. O sujeito fica condenado a sofrer uma insatisfação maior. A sociedade atual é a do espetáculo: vê-se a fama e a visibilidade como os únicos 
critérios que levarão o indivíduo ao lugar almejado. Através do consumo, o narcisismo é acionado por causa desta ilusão de prazer imediato.

\begin{abstract}
Em uma época mais simples, a publicidade meramente chamava a atenção para o produto e exaltava suas vantagens. Hoje em dia, ela procria um produto próprio: o consumidor, perpetuamente insatisfeito, intranquilo, ansioso e entediado. A publicidade serve não tanto para anunciar produtos, mas para promover o consumo como um modo de vida. Ela "educa" as massas para ter um apetite inesgotável não só por bens, mas por novas experiências e satisfação pessoal. Ela defende o consumo como a resposta aos antigos dissabores da solidão, da doença, da fadiga, da insatisfação sexual; ao mesmo tempo, cria novas formas de descontentamentos peculiares à era moderna. Ela joga sedutoramente com o mal-estar da civilização industrial (LASCH, 1983, p. 102).
\end{abstract}

A propaganda e o consumo se juntam em uma espécie de produção e expressão do sujeito narcisista.

\title{
O case The Hire
}

Para análise, foi utilizada a campanha da BMW, The Hire. O case é um bom exemplo da utilização da estratégia de branded content e narrativas digitais.

O branded content é uma técnica que, unindo publicidade e entretenimento, se aproxima do consumidor através de conteúdo relevante. A mensagem não chega de forma intromissiva, como na publicidade tradicional, o conteúdo precisa se buscado pelo público.

A relação entre a marca e o consumidor se fortalece, destacando a marca perante as demais no mercado. Chris Hackley, autor de um livro sobre estratégias de marca, afirma: "Os produtos já não são simplesmente 'colocados'. Eles são transformados em conteúdo de entretenimento abrindo caminho para o possível estabelecimento de uma ligação emocional mais forte com o consumidor".

A estratégia de branded content passou a ser associada a um grande case de sucesso da marca BMW, intitulado The Hire. A campanha, que revolucionou o mercado publicitário, foi composta por uma série de oito curtas-metragens cujas histórias giravam em torno de um carro da marca BMW. Não eram apenas comerciais, eram obras cinematográficas que contavam com a presença de atores e diretores renomados de Hollywood. Usando a técnica de branded content, os "curtas-comerciais" iam ao encontro desse novo consumidor digital - já que foram divulgados exclusivamente pela internet. Apenas $10 \%$ do orçamento foi destinado à promoção dos filmes, o que "obrigou" o consumidor a praticamente buscar por conta própria a mensagem publicitária. Foi uma estratégia arriscada, porém extremamente eficaz, e a campanha tornou-se o ponto inicial - e crucial - para a integração entre publicidade e entretenimento. A BMW estimava, com os vídeos veiculados na internet, atingir dois milhões 
de downloads dos filmes da série. Entretanto, a campanha terminou com 13 milhões de downloads. Com um aumento nas vendas de carros em 12,5\% em relação ao ano anterior, The Hire foi considerada um sucesso, além de ter dado mais prestígio à marca e inúmeros prêmios no meio publicitário.

Com o ator Clive Owen no papel principal, os filmes o mostram como o herói - e motorista de um carro BMW - das diversas aventuras filmadas por aclamados diretores e com participação de famosos atores e celebridades. As situações são várias e bem diferentes de como um produto geralmente é exposto em um comercial: em um dos curtas-metragens, um dos personagens sangra até a morte no banco detrás do carro. O filme não se assemelha a uma publicidade comum, ele entretém o indivíduo, despertando diversos sentimentos nele, estabelecendo uma relação emocional mais forte entre o consumidor e a marca.

Como abordado anteriormente neste artigo, na internet, o consumidor possui a opção de selecionar o conteúdo que lhe interessa, tornando as narrativas digitais segmentadas, já que o conteúdo no meio da internet é segmentado. Esse meio também permite que o usuário, além de selecionar, busque o conteúdo que lhe interessa. Do ponto de vista do anunciante isso é um desafio, pois sua mensagem deve ser relevante o suficiente para que o consumidor escolha acessá-la e não simplesmente a descarte.

A campanha da BMW segue uma narrativa diferente de um anúncio publicitário tradicional, se assemelhado mais às narrativas cinematográficas. Desta forma, a marca se aproxima do consumidor através do entretenimento. Muitos internautas buscam novas opções de entretenimento. Assim, a marca interage com o público oferecendo exatamente o que ele procura.

Outra característica importante e arriscada da campanha é a pouca verba que foi destinada à veiculação dos filmes, deixando grande parte da comunicação nas mãos do próprio público. Para ter acesso aos curtas-metragens, o internauta deveria ir até o site da marca e fazer um download deles. Aos poucos o número de downloads foi crescendo e popularidade dos filmes foi se espalhando. Grande parte da divulgação da campanha foi feita através de mídia espontânea por internautas que assistiram aos filmes. Pode-se observar aqui uma das principais características que a internet proporciona: a participação ativa do consumidor na vida da marca. Consumir e também gerar conteúdo. Mesmo que o consumidor não tenha feito parte da produção dos curtas, ele contribuiu para a distribuição e disseminação deles. 
A publicidade, neste case, possui os mesmos objetivos de em um comercial tradicional para televisão: atrair o consumidor, despertar o desejo de possuir o produto e direcionar o sujeito à compra para sua satisfação. Todavia, a maneira com que o produto é exposto torna-o mais atraente do que ele já é. O meio utilizado para veiculação e a narrativa adequada a esse meio contribuíram para a forma como o consumidor vê o produto. A tática é impactante e, até mesmo, aparenta ser mais persuasiva do que a tradicional.

Situações de grande tensão, vividas por astros de cinema, com um carro que suporta tantas manobras radicais, podem ser percebidas pelo público como um objeto de desejo. $\mathrm{O}$ indivíduo necessita de tal poder que a publicidade deste carro está oferecendo.

Não é simplesmente ser tradicional e dizer os atributos do seu carro, é mostrar estes atributos de uma forma totalmente inovadora. O consumidor passa a desejar ser o Clive Owen e possuir esta máquina. $\mathrm{O}$ ego passa a falar mais alto e o complexo narcisista vem à tona. Consumir o produto trará ao indivíduo poder, autoestima e a tão procurada felicidade, mesmo que esta seja passageira.

A imagem de forma imóvel, por si só, é impactante na mente do consumidor, contudo a imagem em movimento - o vídeo - torna a representação mais real. Por um momento, a pessoa desliga-se de sua realidade, de si mesma e a realidade é substituída pela imagem da tela. A representação audiovisual funciona como uma fuga nos problemas.

A sociedade que se baseia na imagem é abordada por Guy Debord na obra $A$ Sociedade do Espetáculo. Nela, Debord aponta para uma sociedade mais preocupada com a representação do que com a realidade: "Toda a vida das sociedades nas quais reinam as modernas condições de produção se apresenta como uma imensa acumulação de espetáculo. Tudo o que era vivido diretamente tornou-se uma representação" (DEBORD, 1997, p. 13).

Este espetáculo levantado por Debord é uma forma de sociedade na qual a realidade é deficiente e pobre. Os indivíduos buscam consumir as imagens do que não está presente na sua realidade. O que lhes falta em suas vidas é substituído pela imagem, em consequência, estas imagens acabam tornando-se a realidade deste homem.

Antes as pessoas se preocupavam em "ter" as coisas, possuir objetos. Hoje elas se preocupam mais em "parecer", projetar uma imagem ideal perante a sociedade. O "parecer ser" torna-se mais importante do que o próprio "ser".

A primeira fase da dominação da economia sobre a vida social acarretou, no modo de definir toda realização humana, uma evidente degradação do ser para o ter. A fase atual, em que a vida social está totalmente tomada pelos resultados acumulados da economia, leva a um deslizamento generalizado do ter para o parecer, do qual todo "ter" efetivo deve extrair prestígio imediato e sua função última. Ao mesmo 
tempo, toda realidade individual tornou-se social, diretamente dependente da força social, moldada por ela. Só the é permitido aparecer naquilo que ela não é (DEBORD, 1997, p. 18).

Esse "parecer" irá trazer para o indivíduo a necessidade de poder - despertada nos filmes da The Hire - nos quais o objeto de desejo não é apenas o carro, porque ao possuir o carro o consumidor, inconscientemente, acredita que terá o poder que o Clive Owen tem, podendo fazer as mesmas manobras com o veículo, passando por situações de adrenalina da mesma forma.

Em uma análise focada em um dos filmes da série, Beat the Devil (Vencendo o Diabo), pode-se observar traços dos conceitos abordados durante o artigo. O filme inicia com o mítico James Brown interpretando a si próprio. O motorista Owen o leva para uma reunião com o Diabo, interpretado por Gary Oldman. Brown busca modificar o contrato feito com o Diabo quando ainda era jovem, pois nesse contrato lhe foi prometido juventude e fama eterna, entretanto Brown reclama ao Diabo que está envelhecendo. Pode-se traçar uma semelhança com Dorian Gray, que também almejava essa juventude eterna. Como citado anteriormente, esta busca pela imagem perfeita é uma das características do narcisismo.

O Diabo, então, propõe a James Brown e seu motorista que ganhem dele numa corrida de carro para que o pedido seja realizado. A partir deste momento, o filme mostra os atributos do carro, de maneira sutil, sem interferir na história. Pode-se perceber que o desejo começa a ser despertado a partir dessa sequência de cenas, em que o telespectador torce para que Brown e Owen vençam o Diabo. Além de o desejo ser direcionado ao produto, nasce uma identificação também com os personagens, ou seja, o consumidor quer o carro e inconscientemente - o poder de ser o herói e salvar o dia. Após uma corrida eletrizante, eles ganham do Diabo, que morre, e James Brown volta a ser jovem. O seu desejo foi realizado e a busca pela felicidade finalmente é alcançada. No telespectador, o sentimento de realização também é despertado. O narcisismo atinge seu ápice.

\section{Considerações finais}

Como visto, a primeira parte do artigo trouxe uma breve reflexão sobre o crescimento da internet a as novas narrativas que seguem com ela. Ao analisar esses conceitos no case da BMW, observou-se que a forma de comunicação utilizada para alcançar e atrair o públicoalvo foi perfeitamente adequada ao meio em que foi divulgada. Pois o internauta tende à segmentar seu conteúdo e buscar apenas o que lhe é relevante. 
A campanha explorou a técnica de branded content ao oferecer esse conteúdo relevante - de entretenimento - ao seu consumidor, atraindo-o ao site da marca para baixar o conteúdo do filme.

Como visto na sequência, foi abordado o narcisismo, característica que está diretamente ligada à individualização do ser humano que é cada vez mais evidente na sociedade atual. Além disso, o indivíduo narcisista necessita de poder, de autoafirmação e consumir determinados produtos que podem lhe dar este poder.

As condições sociais predominantes tendem [...] a fazer aflorar os traços narcisistas presentes, em vários graus, em todos nós. Estas condições também transformaram a família, que por sua vez modela a estrutura subjacente da personalidade (LASCH, 1983, p. 76).

Para exemplificar melhor os conceitos abordados, foi analisado o filme Beat the Devil, do case The Hire, da BMW. No filme, as diversas manobras realizadas com o carro da marca despertam o desejo do consumidor em não apenas possuir o veículo, mas ser tão bom quanto o "herói" que o dirige no filme. Na história, James Brown busca permanecer eternamente jovem, uma característica claramente narcisista.

Ao analisar as narrativas digitais e suas características particulares, observou-se que o consumidor passou a produzir conteúdo além de apenas consumi-lo. Isso traz ao consumidor uma sensação de poder, que está presente no indivíduo narcisista.

Em casos de lutas sociais, como a autora Pollyana Ferrari aborda, o internauta tem uma participação ativa muito grande, podendo proporcionar reais mudanças.

Ao ter consciência de que pode efetuar essas reais mudanças, esse indivíduo conectado pode optar por usar esse poder para causas ditas "nobres" ou para benefício próprio. Concluindo que, seja intencionalmente ou não, a liberdade que a internet traz aos seus usuários contribui para a formação de um indivíduo narcisista.

\section{REFERÊNCIAS}

DEBORD, Guy. A sociedade do espetáculo. Rio de Janeiro: Contraponto, 1997.

DONATON, Scott. Publicidade + Entretenimento: por que estas duas indústrias precisam se unir para garantir a sobrevivência mútua. São Paulo: Cultrix, 2007.

FREUD, Sigmund (1915). Os instintos e suas vicissitudes. In: . A história do movimento psicanalítico, artigos sobre metapsicologia e outros trabalhos. Rio de Janeiro: Imago, 1976. p. 129-163.

JENKINS, Henry. Cultura da convergência. São Paulo: Aleph, 2008.

LASCH, C. A cultura do narcisismo. Rio de Janeiro: Imago, 1983. 
DITO EFEITO - ISSN 1984-2376 ANO IV, Vol. 4, N.o 5, Jul.-Dez. 2013 UTFPR-CAMPUS CURITIBA

MARQUEZ, Allan Cancian. MALINI, Fabio Luiz. \#Spanishrevolution: internet e narrativas das lutas sociais no Twitter. Recife: XXXIV Congresso Brasileiro de Ciências da Comunicação, 2011. 